\title{
Introduction to the Study of Mechanical Properties of Terpolymer PP/EPDM Mixtures
}

\author{
Sandra R. Scagliusi ${ }^{1,2, *}$, Elizabeth C.L. Carvalho ${ }^{1,3}$ and Ademar B. Lugão $0^{1,4}$ \\ ${ }^{1}$ Instituto de Pesquisas Energéticas e Nucleares (IPEN / CNEN - SP) Av. Professor Lineu Prestes 2242, \\ 05508-000 São Paulo, SP, Brazil \\ ${ }^{2}$ Rua Natal 386, apto 134, CEP 03186-030, S.Paulo, Brazil \\ ${ }^{3}$ Av. Rebouças 1511, apto.64, CEP 05402-100, S. Paulo, Brazil \\ ${ }^{4}$ Rua Saldanha Gama, 268, CEP 05081-000, São Paulo, 05508-000, Brazil
}

\begin{abstract}
Thermoplastic elastomers (TPEs), based in PP (Polypropylene) / EPDM (Ethylene Propylene Diene Monomer) have as purpose improving PP resistance and impact, aiming to a more comprehensive use in automotive market, among edifications, construction and packaging sectors, due to their recyclability properties. PP is a commodity, with a high melting point, high mechanical resistance and low density, posing a balance between physical and mechanical properties; in addition, it shows an easy processing, at low cost. In order to minimize this deficiency, EPDM, an impact modifier, can be used. Nevertheless, most of polymeric blends are incompatible and immiscible, i.e., show a mutual and limited solubility and in most of cases, a high interfacial tension. However, there is a relatively low interfacial tension (force which acts on transformation of a continuous structure in a dispersion) between PP and EPDM (approximately $0.3 \mathrm{mN} \cdot \mathrm{m}^{-1}$ ), reducing the rate of breakup and facilitating the build-up of a continuous structure. This work aims to the study of compatibility of PP and EPDM blends and variation of mechanical properties, emphasizing that many properties of thermoplastic elastomers can be processed according with conventional thermoplastics methods: herein, PP/EPDM blends, 90/10, 80/20, 70/30 and 50/50 were characterized according to: Mechanical essays, Differential Scanning Calorimetry, Thermogravimetric Analyses, Melt Flow Index, Izod Impact Strength and Dynamic mechanical Analyses.
\end{abstract}

Keywords: TPE, Elastomers, thermoplastics, polymer blends, compatibility.

\section{INTRODUCTION}

Elastomeric thermoplastics are included in materials family similar to rubbers that, on contrary of conventional thermosetting rubber, are able to be reprocessed and recycled enabling this way the reutilization of process scraps and wastes [1]. In addition, TPEs produce lighter parts, with production cycles shorter and faster. They are processed by the same equipment used in traditional thermoplastics, on contrary of vulcanized rubbers $[2,3]$.

Search for new materials has been an industry demand. For many years, various chemical compounds were found and many other synthesized and tested for polymers production without aimed success, considering that many of these materials did not show expected final properties for technological application.

The requirement for the development of new materials, specifically those ones with multiple physical-mechanical properties, conflicted with the

*Address correspondence to this author at the Chemistry and Environment Center, (Polymer Laboratory), Institute for Energy and Nuclear Research (IPEN), Butantã, São Paulo, Brazil; Tel: +5511992516346;

E-mail: scagliusi@usp.br complexity of rubber formulations, the use of raw materials of rising cost and in the difficult processing control of these formulations. These technological demands resulted often in a high financial cost [4].

Solution found to deal with this problem was the development of polymeric mixtures, i.e., the production of materials from the combination of two or more different polymers. This strategy enabled combining, in a single material, various physical-mechanical properties, without the need of development of new processes or the accomplishment of synthesis of new monomers $[1,5,6]$. The development of these materials leads to a new and special type of industry, the thermoplastics industry (TPEs) [7]

TPE-Vs Polypropylene (PP) base and ethylenepropylene-diene (EPDM) copolymer represent the most representative of this class of materials $[8,9]$. They are used specially in auto industry for the manufacturing of parts as profiles, hoses and bumpers, pointing to other segments with use in various products as toothbrushes, tools and cable insulation $[10,11]$.

TPEs block styrene copolymers base was commercially introduced in 1965 , creating a great 
interest in rubber industry $[12,13]$. Since then, applications in the market are still growing, and fulfill various segments, either in rubber or in thermoplastic industry. Commercially relevant TPEs are divided into three categories:

a) Block copolymers that contain rigid and flexible segments, styrene, co-polyesters, polyurethane and polyamides type;

b) rubber/thermoplastic blends (TPE-O) and

c) vulcanized thermoplastics elastomers (TPE-Vs) $[14,15]$.

Elastomers and thermoplastics resins blends are called olefin thermoplastic elastomer (TEOs) or polyolefin thermoplastic elastomers (TPE-O) and are constituted in the great majority of elastomers and olefin thermoplastics. The most used thermoplastics are Polypropylene (PP), Polyethylene (PE) and Ethylene/Vinyl Acetate Copolymer (EVA). Among used elastomers, Ethylene Propylene Rubber (EPR) and Ethylene Propylene Diene (EPDM), thermoplastic elastomers styrene copolymers block type, as SBS and SEBS $[16,17]$.

The most common example is the PP and EPDM blend [18]. Morphology of these blends is constituted by EPDM rubber disperse in a continuous PP matrix, with EPDM contents $30 \%$ maximum. In general, EPDM is used to improve PP impact properties $[19,20]$.

PP and EPDM composites base represent a relevant commercially example: EPDM is provided with a saturated main chain and consequently exhibits excellent stability to heating and to ozone; PP, due to its high melting point and crystallinity, exhibits good resistance to oils and to heating. Besides, both polymers are compatible due to their similar chemical structure [21].

This work aims to the study of PP/EPDM blends, EPDM varying from zero to $50 \%$, in order to achieve satisfactory tensile strength and resistance to impact.

\section{MATERIALS AND METHODS}

For PP/EPDM blends, there were used materials as received, i.e., without incorporating additive or compatibilizer.

- $\quad$ Polypropylene (PP): PP-440K, Quattor/Braskem, $3.5 \mathrm{~g} / 10$ minutes M.F.I.

- $\quad$ Ethylene Propylene Diene Monomer (EPDM): Keltan 5470, Lanxess, Mooney viscosity 55, at $125^{\circ} \mathrm{C}$, containing $70 \%$ ethylene, 25\% propylene, $4.6 \%$ ENB, $39 \%$ crystallinity.

\subsection{Samples Preparation}

Blends composition is presented in Table 1. At first, samples were compounded on a 3.1 L/D, 19/33 compression ratio twin-screw co-rotating extruder (HAAKE Rheomex $332 p$ ), temperatures $175-200^{\circ} \mathrm{C}, 60$ rpm:

The Figure 1 shows the extruder where the samples were prepared.

Table 1: Samples Composition, Parts by Weight

\begin{tabular}{|c|c|c|c|c|c|c|}
\hline Components & \multicolumn{5}{|c|}{ Quantities } \\
\hline \hline PP & 100 & 90 & 80 & 70 & 50 & - \\
\hline EPDM & ---- & 10 & 20 & 30 & 50 & 100 \\
\hline
\end{tabular}

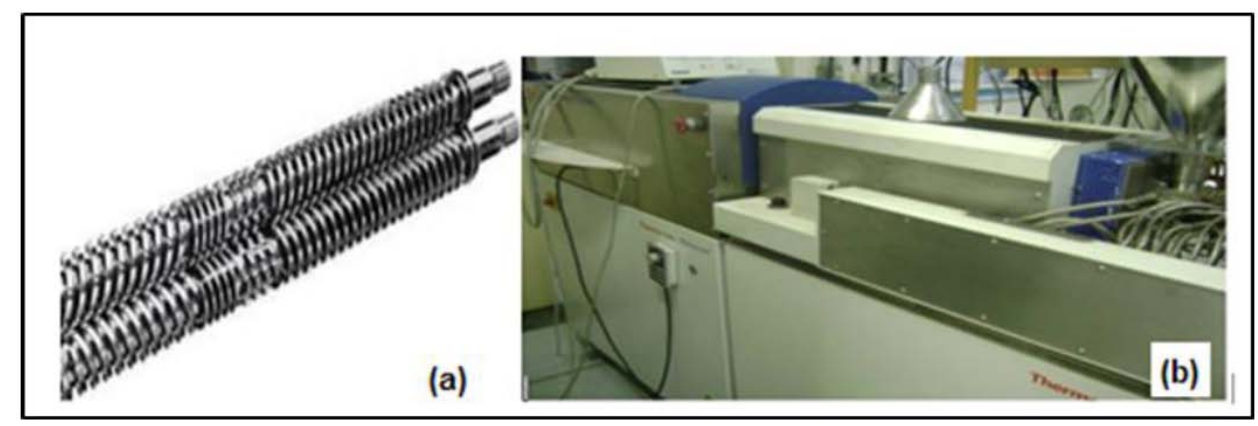

Figure 1: Twin-screw (a) and co-rotating extruder (b). 


\subsection{Methods}

Analyses were accomplished in triplicate for results achievement and characterized by following methods:

\subsubsection{Mechanical Essays}

TA-Hdi texture analyzer, $5 \mathrm{~kg}$ load cell, $0.5 \mathrm{~m} / \mathrm{s}$ deformation rate, $2 \mathrm{~mm} / \mathrm{s}$ crosshead speed, in accordance with ASTM D 638-08 [22]. Stress-strain tests were performed at room temperature.

Texture is a very important physical attribute in that it affects processing, handling, used to measure the properties related to the way the material behaves when subjected to a force, breaking, and either flowing, stretching or bending.

\subsubsection{Thermal Behavior}

It was examined in a DSC Mettler Toledo apparatus, according to ASTM D 3418-08 - Standard Test method for Transition Temperatures and Enthalpies of Fusion and Crystallization of Polymers by Differential Scanning Calorimetry [23], by using $5-9$ $\mathrm{mg}$ of sample, within a 25 to $300^{\circ} \mathrm{C}$ program, at $10^{\circ}$ $\mathrm{C} / \mathrm{min}$, under a nitrogen flow of $50 \mathrm{ml} / \mathrm{min}$.

\subsubsection{Thermogravimetric Analyses (TG)}

It provides complimentary and supplementary characterization information to DSC, by measuring the amount and rate (velocity) of change in the mass of a sample as a function of temperature or time in a controlled atmosphere. Measurements are used primarily to determine the thermal and/or oxidative stabilities of materials as well as their compositional properties. The technique can analyze materials that exhibit either mass loss or gain due to decomposition, oxidation or loss of volatiles (such as moisture). TGA in pellets samples were performed using a DSC Mettler



(a)
Toledo apparatus, according to ASTM E 1641-07 Standard Test method for Decomposition Kinetics by Thermogravimetry [24], by using $5-9 \mathrm{mg}$ of sample, within a 25 to $600^{\circ} \mathrm{C}$ program, at a $10^{\circ} \mathrm{C} / \mathrm{min}$, in a nitrogen flow of $50 \mathrm{ml} / \mathrm{min}$.

\subsubsection{Melt Flow Index}

It was accomplished in a CEAST apparatus, modular line, $230^{\circ} \mathrm{C}, 2.16 \mathrm{~kg}$ load, 240 seconds preheating time, according to ASTM D-1238-13 [25]. The Mass Flow Index (MFI) or Mass Flow Rate (MFR) is a measure of the "ease" of flow of molten plastic resins and is often used by the plastics industries for quality control of thermoplastics.

\subsubsection{Izod Impact Strength}

It was performed according to ASTM D-256-10 [26]; this technique allows the evaluation of rupture strength of plastic materials when subjected to impact by bending or abrupt forces.

\subsubsection{Dynamic Mechanical Analyses (DMA)}

Storage modulus, dissipation modulus and $\tan \delta$ analyses constitute a relevant tool for the study of viscoelastic properties. It was used a TA DMA 2980 equipment, sample holder for flexion in two points, according to ASTM D 4065 [27]. Evaluated temperature range was $25^{\circ}$ to $190^{\circ} \mathrm{C}$, at $2^{\circ} \mathrm{C} / \mathrm{min}$ heating speed. Frequency was $2 \mathrm{~Hz}$ and $60 \mu \mathrm{m}$ amplitude, or approximately, $2 \times 10^{-5}$ deformation.

\section{RESULTS AND DISCUSSION}

\subsection{Mechanical Essays}

In this test, the elasticity module that represents the material stiffness is measured; thus, the greater the modulus of elasticity, the less the elastic deformation caused by a given tension, and the more rigid the



(b)

Figure 2: Tensile $x$ deformation curve (a) PP and (b) EPDM. 


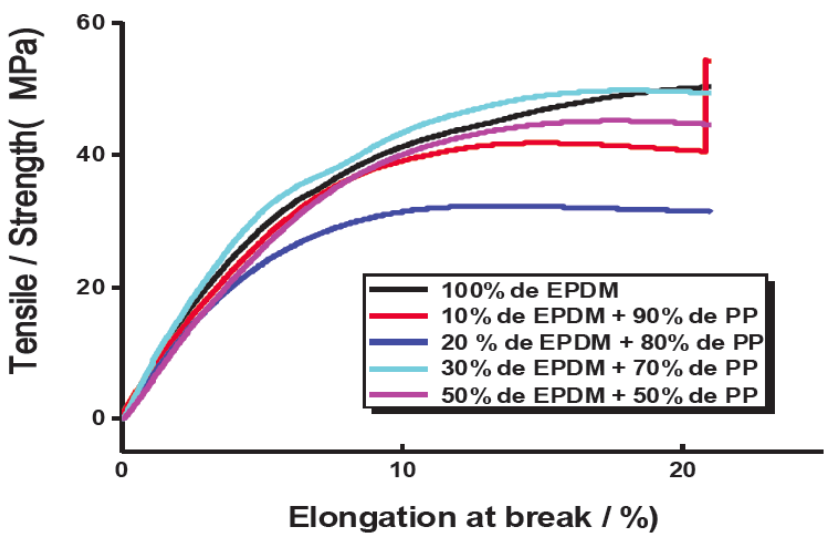

Figure 3: Mechanical behavior of PP/EPDM blends.

material. In the case of elastomers, if the load is released in this region, at any point on the line, the material returns to the point of origin in this way it is possible to assess whether the material resists a certain force exerted on it.

Stress-strain curve for PP is shown in Figure $2 \mathrm{a}$; it can be observed that the polymer has a behavior highly ductile, with tightening and extensive flow of specimen and occurrence of rupture after a great deformation. When compared with tensile deformation for EPDM, as shown in Figure $\mathbf{2 b}$, it is observed an elastic deformation, i.e., deformation proportional to applied force [28]

Stress-strain curve for PP and mixtures with EPDM are represented in Figure 3 . Tensile deformation curve for PP showed that the polymer presents a behavior typical of a material that suffers rupture after a deformation.

The test measured the elastic region that represents the elastic behavior of the material; in this region, the deformation is directly proportional to the applied load, obeying Hooke's law [29].
$\sigma=E, \epsilon$

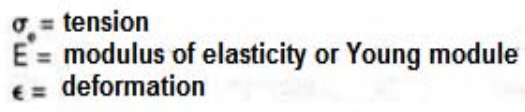

The elastic modulus $(E)$ or the stiffness of the mixtures is shown in Figure 3, EPDM $(E=5 \mathrm{MPa})$ is a softer material than PP $(E=2.85 \mathrm{Mpa})$ and therefore, as expected, the addition EPDM results in a increase in $E$ values. This can be clearly seen in Figure 3 ( $E$ values between 20 and $40 \mathrm{MPa}$ ). In summary, it can be affirmed that addition of EPDM to PP contributed for a raise in tensile, for all blends.

\subsection{Thermal Behavior}

In DSC analyses, all samples were previously heated in temperatures higher than melting point, further cooled to room temperature, before the second scanning. A higher melting temperature is associated to a higher sample stability. A reduction in melting point suggests that the crystallinity and a perfection in crystalline structure are prejudiced; all EPDM/PP blends showed a lower melting point and consequently, a lower crystallinity. A change in crystalline structure can result from polymer-polymer interactions in amorphous phase; so, it is created crystals disorder, reducing phase changing enthalpy and consequently, the crystallinity [30].

DSC thermal behavior for PP/EPDM blends is presented in Table 2

Figure 4 presents enthalpy variation for PP/EPDM blends. DSC results emphasized that EPDM addition caused a light increase in blends melting point. On the other hand, crystallization degree was reduced with EPDM addition to PP matrix.

Table 2: DSC Thermal Behavior of Blends PP/EPDM

\begin{tabular}{|c|c|c|c|c|c|c|c|}
\hline & $\begin{array}{c}\Delta \mathrm{H}_{1} \\
\left(1^{\mathrm{st}} \mathrm{h}\right) \\
{[\mathrm{mJ}]}\end{array}$ & $\begin{array}{c}\mathrm{T}_{\mathrm{m} 1} \\
\left(1^{\mathrm{st}} \mathrm{h}\right) \\
{[\mathrm{C}]}\end{array}$ & $\begin{array}{l}\mathbf{X}_{\mathrm{c1}} \\
{[\%]}\end{array}$ & $\begin{array}{c}\mathrm{T}_{\mathrm{c}} \\
\left(1^{\mathrm{st}} \mathrm{c}\right) \\
{[\mathrm{mJ}]}\end{array}$ & $\begin{array}{c}\Delta \mathrm{H}_{2} \\
\left(2^{\text {nd }} \mathrm{h}\right) \\
{[\mathrm{mJ}]}\end{array}$ & $\begin{array}{c}\mathrm{T}_{\mathrm{m2}} \\
\left(2^{\mathrm{nd}} \mathrm{h}\right) \\
{[\mathrm{C}]}\end{array}$ & $\begin{array}{l}\mathbf{X}_{\mathrm{C2}} \\
{[\%]}\end{array}$ \\
\hline PP & 304.0 & 180.9 & 37.3 & 121.0 & 352.3 & 172.9 & 40.1 \\
\hline EPDM & 87.3 & 180.0 & 39.0 & 127.1 & 295.6 & 176.9 & 39.0 \\
\hline $10 \%$ EPDM in $90 \%$ PP & 88.7 & 180.8 & 35.6 & 121.1 & 376.0 & 173.7 & 42.7 \\
\hline $20 \%$ EPDM in $80 \%$ PP & 98.0 & 180.0 & 30.2 & 127.0 & 319.2 & 175.0 & 37.9 \\
\hline $30 \%$ EPDM in $70 \%$ PP & 275.6 & 180.2 & 29.3 & 126.6 & 327.9 & 177.7 & 34.1 \\
\hline $50 \%$ EPDM in $50 \%$ PP & 285,3 & 180,4 & 28,9 & 125,4 & 334,6 & 178,1 & 33,4 \\
\hline
\end{tabular}

Where: $\Delta H_{1}$ and $\Delta H_{2}$ are melt enthalpies related to first and second heating, respectively; $T m_{1}$ and $T m_{2}$ are melt temperatures related to first and second heating, respectively; $\mathrm{Tc}=$ crystallization temperature; $\mathrm{Xc}_{\mathrm{C}_{1}}$ and $\mathrm{Xc2}$, crystallinity related to $1 \mathrm{st}$ and $2 \mathrm{nd}$. 




Figure 4: DSC thermal behavior for EPDM/ PP blends.

(a)

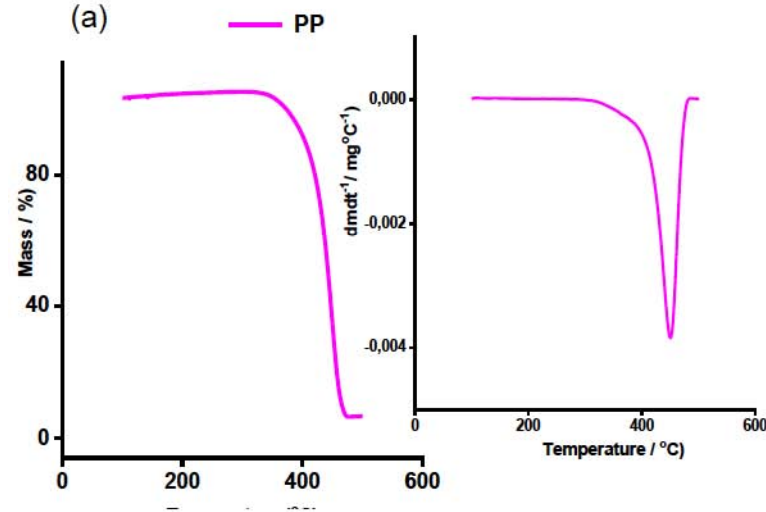

(b) - EPDM

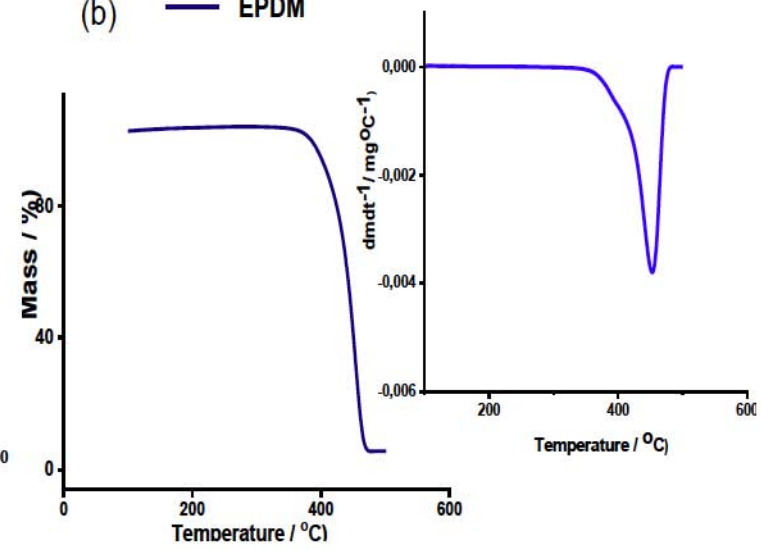

Figure 5: TGA behavior of PP (a) and EPDM (b).

\subsection{Thermogravimetric Analyses (TG)}

The same procedure previously described for DSC was followed by TGA investigations. Figures $\mathbf{5 a}$ and $\mathbf{5 b}$ show thermal degradation for PP and EPDM. It is observed that decomposition temperature for PP is lower than that one presented by EPDM, pointing toward a higher thermal stability for EPDM.

TGA results for PP/EPDM blends are shown in Figure 6, indicating a very close thermal degradation behavior.

Table $\mathbf{3}$ validate behavior shown in Figures $\mathbf{5}$ and $\mathbf{6}$, indicating for EPDM/PP blends values for $\mathrm{T}_{\text {onset }}$ (initial degradation temperature) higher than those ones obtained for PP. It was found an average of $6.0 \%$ mass loss (residue) in evaluated samples, that corresponds to remaining degraded amount at temperatures higher than $600{ }^{\circ} \mathrm{C}$, corroborating literature values, $\mathrm{PP}$ has a degradation temperature of $340^{\circ} \mathrm{C}$ to $440^{\circ} \mathrm{C}$ [31].

\subsection{Melt Flow Index}

Melt Index (MI), Melt Flow Index (MFI) or Melt Flow Ratio (MFR) corresponds to grams within 10 minutes flowing through a standardized die according to ASTM $\mathrm{D}-13$, under a specified load, at $230^{\circ} \mathrm{C}$, using PP as

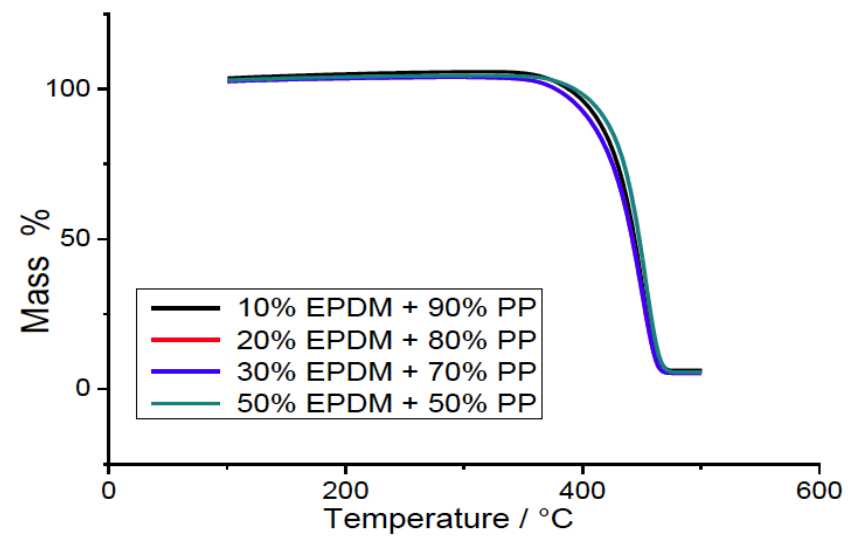

Figure 6: TGA curves for PP/EPDM blends. 
Table 3: TGA Behavior of PP, EPDM and PP/EPDM Blends

\begin{tabular}{|c|c|c|c|}
\hline & $\begin{array}{l}\mathrm{T}_{\text {onset }} \\
{\left[{ }^{\circ} \mathrm{C}\right]}\end{array}$ & $\begin{array}{c}\mathbf{T}_{\text {peak }} \\
{\left[{ }^{\circ} \mathrm{C}\right]}\end{array}$ & $\begin{array}{c}\text { Residue } \\
\text { [\%] }\end{array}$ \\
\hline PP & 373.5 & 450.0 & 6.9 \\
\hline EPDM & 391.7 & 450.0 & 5.6 \\
\hline $10 \%$ EPDM in PP $90 \%$ & 389.4 & 420.0 & 6.6 \\
\hline $20 \%$ EPDM in PP $80 \%$ & 399.6 & 450.0 & 7.0 \\
\hline $30 \%$ EPDM in PP $70 \%$ & 391.6 & 450.0 & 5.3 \\
\hline $50 \%$ EPDM in PP $50 \%$ & 397.8 & 450.0 & 5.7 \\
\hline
\end{tabular}

where: $\mathrm{T}_{\text {onset }}=$ initial thermal degradation temperature in each stage; $\mathrm{T}_{\text {peak }}=$ thermal degradation peak temperature in each stage; Residue $=$ remaining degraded sample amount, at temperature higher than $600^{\circ} \mathrm{C}$

Table 4: $\quad$ Melt Flow Index of PP/EPDM Blends

\begin{tabular}{|c|c|c|c|c|c|}
\hline & PP & $\begin{array}{c}\text { \% EPDM } \\
\text { in PP }\end{array}$ & $\begin{array}{c}\mathbf{2 0 \%} \text { EPDM } \\
\text { in PP }\end{array}$ & $\begin{array}{c}\mathbf{3 0 \%} \text { EPDM EPDM } \\
\text { in PP }\end{array}$ \\
\hline \hline $\begin{array}{c}\text { M.F.R. at } 230^{\circ} \mathrm{C} \\
\left.\text { in PP } 10 \mathrm{~min}^{-1}\right)\end{array}$ & 3.6 & 3.4 & 2.7 & 1.9 & 1.4 \\
\hline
\end{tabular}

reference. MFR is an indicator of medium molecular weight and is inversely proportional to it; that is, a resin that exhibits a MFR of $50 \mathrm{~g} / 10$ min indicates a lower molecular weight when compared to another resin showing a MFR equal to $10 \mathrm{~g} / 10 \mathrm{~min}$.

Table 4 shows MFR evaluations for PP/EPDM blends; a higher addition of EPDM to PP reduced MFR and consequently, will contribute for compounds with higher molecular weight.

\subsection{Izod Impact Strength}

Data extracted from Impact essay show the ability of polymers in absorbing applied energy within a short time interval. Izod essay is generally accomplished in a $3.2 \mathrm{~mm}$ thickness sample. In general, resistance to impact increases in function of molecular weight [32]. In Figure 7 are shown results obtained for impact analyses in PP/EPDM blends.

According to shown in Figure 7, impact values obtained for EPDM are superior to those ones found for PP. All PP/EPDM blends showed impact values higher than EPDM (rubbery matrix).

Miscibility or phases segregation extension in blends can be evaluated by DMA. One of criteria for evaluation of miscibility in blends is glass transition analysis. Under this criterion, a blend is considered miscible when presents a single glass transition within an intermediary temperature range related to the components.

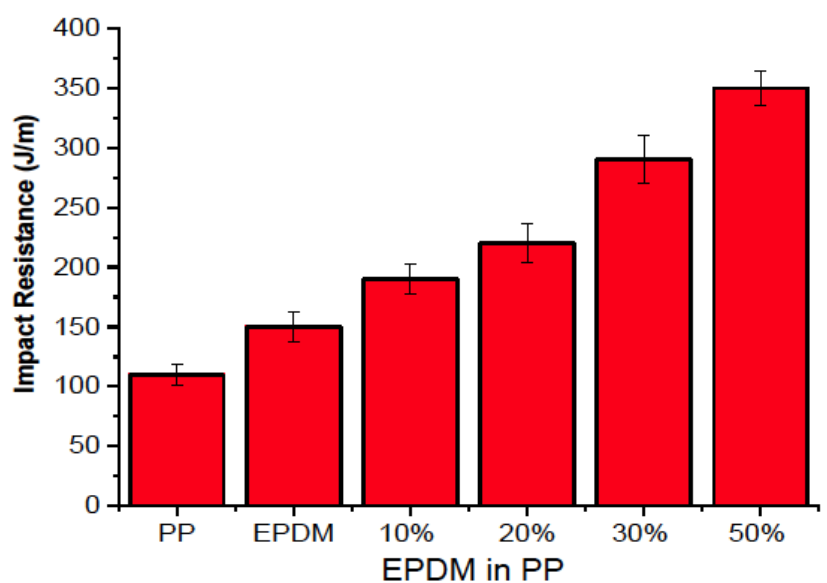

Figure 7: Impact resistance for PP, EPDM and their blends.

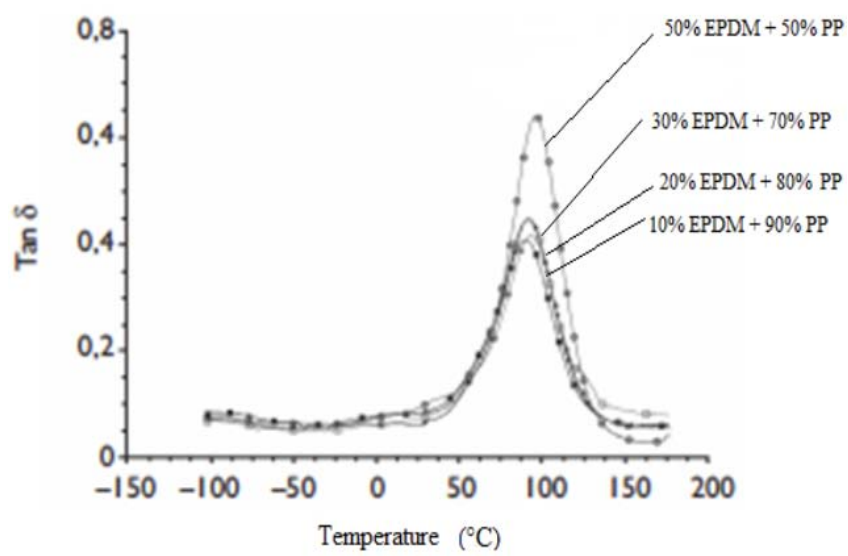

Figure 8: Glass transition for PP/EPDM blends. 


\subsection{Dynamic Mechanical Analyses (DMA)}

Figure 8 shows results for tan $\delta$ corresponding to PP and PP/EPDM blends; was observed that glass transition $(\mathrm{Tg})$, thermoplastics phase is not well defined. In literature, it was mentioned that for low content of thermoplastic, the peak is practically nonvisible [33]. This result can be attributed to the high compatibility between PP and EPDM phases.

\section{CONCLUSION}

EPDM to PP addition, at 10, 20, 30 and $50 \%$ levels, contributed for providing effective PP/EPDM blends interaction, contributing to satisfactory stress-strain and resistance to impact results. It was verified a lower melting and crystallization temperatures for all evaluated samples and a higher thermal stability was presented by PP/EPDM blends.

EPDM contributed for a decreasing in melting index in PP/EPDM mixtures pointing toward a material with a higher molecular weight.

Based in thermomechanical properties for investigated samples it can be verified that $\mathrm{Tg}$ in PP/EPDM blends is reduced depending on EPDM amount added to PP. It was verified that PP/EPDM blends are practically miscible.

\section{ACKNOWLEDGEMENTS}

The authors acknowledge CBE, Braskem, Lanxess and IPEN, fundamental for work development.

\section{RESPONSIBILITY NOTICE}

The authors are the only responsible for the printed material included in this paper.

\section{REFERENCES}

[1] Payne MT, Rader CP. Thermoplastic Elastomers: a rising star. In: Cheremisinoff, N.P. Elastomer Technology Handbook. Boca Raton: CRC Press, 1993; pp. 557-595. https://doi.org/10.1201/9780138758851-14

[2] Holden G, Legge NR, Quirk R, Schroeder HE. In Thermoplastic Elastomers; Editora: Hanser Publishers: Munich, 1987; p. 573.

[3] Furtado AM, Peres ACC, Nunes RCR, Visconte LLY, Polímeros: Ciência e Tecnologia, 2001; p. 11. https://doi.org/10.1590/S0104-14282001000100006

[4] Jury JR, Chien WY. Thermoplastic Elastomer Composition, US 6,262,175 B1, (2001).

[5] Kresge EN. Polyolefin thermoplastic elastomer blends; Rubber Chemistry and Technology 1991; 64: 469-479. https://doi.org/10.5254/1.3538564
[6]

Fernandes DM. Estudo da estabilidade térmica de misturas de poli(álcool vinílico)/lignina modificada. Dissertação (Mestrado em Química) - Departamento de Química, Centro de Ciências Exatas, Universidade Estadual de Maringá, Paraná, 2005.

[7] Mark HF. Polymer Blends In Encyclopedia of Polymer Sceince and Technology, $3^{\text {a }}$ edição, John Wiley \& Sons, 2005.

[8] Marson JA. Polymers Blends and composites. New York: Plenum Press, 1976; p. 515.

[9] Furtado AM, Peres ACC, Nunes RCR, Visconte LLY, Polímeros: Ciência e Tecnologia, 2001; p. 11. https://doi.org/10.1590/S0104-14282001000100006

[10] Jury JR, Chien WY. Thermoplastic Elastomer Composition, US 6,262,175 B1, (2001).

[11] Zhao R, Dai G. Mechanical property and morphology comparison between the two blends poly(propylene)/ ethylene-propylene-diene monomer elastomer and poly(propylene)/maleic anhydride eg-ethylenepropylenediene monomer Journal of Applied Polymer Science, 2002; 86: 2486-2491. https://doi.org/10.1002/app.11003

[12] Ezzati P, Ghasemi I, Karrabi M, Azizi H. Correlation between the rheological behavior and morphology of PP/EPDM blend in various dynamic vulcanization systems, IRAN Polymer Journal 2008; 17: 1-8.

[13] Van Duin M. Recent Developments for EPDM-Based Thermoplastic Vulcanisates Macromolecular. Symposia, 2006; 233(11): 11-16. https://doi.org/10.1002/masy.200690006

[14] Rocha EC, Lovison VMH, Pierozan NJ. Tecnologia de Transformações dos Elastômeros; Centro Tecnológico de Polímeros SENAI: São Leopoldo 2003.

[15] Payne MT, Rader CP. In Elastomer Technology Handbook; Cheremisinoff, N. P. Editora: CRC Press: Boca Raton, 1993; p. 557.

[16] Sengupta P, Noordermeer JWM. Effects of Composition and Processing Conditions on Morphology and Properties of Thermoplastic Elastomer Blends of SEBS-PP-Oil and Dynamically Vulcanized EPDM-PP-Oil. Journal of Elastomers e Plastics 2004; 36(4): 307-331. https://doi.org/10.1177/0095244304042668

[17] Prut E, Medintseva T, Dreval V. Mechanical and Rheological Behavior of Unvulcanized and Dynamically Vulcanized PP/EPDM Blends, Macromoleculr Symposia 2006; 233: 7885.

https://doi.org/10.1002/masy.200690031

[18] Coran AY, Patel RP. Rubber-Thermoplastic Compositions Part IV Thermoplastic Vulcanizates from various Rubber Plastic Combinations Rubber Chem. Technol, 1981,v.54, p. 892, (1981) apud Drobny, J. G. Handbook of Thermoplastic Elastomers. New York: Plastics Design Library, cap.2, 2007; p. 10.

https://doi.org/10.5254/1.3535842

[19] Sarkhel G, Choudhury A. Dynamic vulcanization of polyethylene-based thermoplastic elastomer blends, Journal of Applied Polymer Science 2009; 115(1): 376-384. https://doi.org/10.1002/app.30285

[20] Machado MAL, Arroyo M. New developments in dynamically cured PP-EPDM blends, Rubber Chemistry and Technology 2001; 74: 211-220. https://doi.org/10.5254/1.3544945

[21] Choudhary V, Varmal HS, Varma K. Polyolefin blends: effect of EPDM rubber on crystallization, morphology and mechanical properties of polypropylene/EPDM blends, Polymer 1991; 32(14): 2534-2540. https://doi.org/10.1016/0032-3861(91)90332-D 
[22] American Society for Testing and Materials - D 638-08. Standard test methods for tensile properties of plastics. EUA: 2008; p. 15

[23] American Society for Testing and Materials - D 3418-08 Standard Test method for Transition Temperatures and Enthalpies of Fusion and Crystallization of Polymers by Differential Scanning Calorimetry. EUA: 2008; p. 17.

[24] American Society for Testing and Materials - ASTM E 164107 - Standard Test method for Decomposition Kinetics by Thermogravimetry. EUA: 2007; p. 25.

[25] American Society for Testing and Materials - ASTM D 123813 - Standard Test method for Melt Flow Rates of Thermoplastics by Extrusion Plastometer. EUA: 2013; 16.

[26] American Society for Testing and Materials - ASTM D 25610 - Standard Test Methods for Determining the Izod Pendulum Impact Resistance of Plastics. EUA: 2018; p. 20.

[27] American Society for Testing and Materials - ASTM D 406512 - Standard Practice for Plastics: Dynamic Mechanical Properties: Determination and Report of Procedures. EUA: 2012; p. 7.

[28] Canevarolo SV Jr. "Ciência dos Polímeros - Um texto básico para tecnólogos e engenheiros"; Editora Artliber; $2^{\mathrm{a}}$ edição; São Paulo, 2006; pp. 203-208.

[29] Gupta N, Jain A, Singhal R, Nagpal AK. Effect of dynamic crosslinking on tensile yield behavior of polypropylene/ethylene-propylene-diene rubber blends. Journal of Applied Polymer Science 2000; 78: 2104-2121.

https://doi.org/10.1002/1097-

4628(20001213)78:12<2104::AID-APP60>3.0.CO;2-7

[30] Guirguis OW, Moselhey $\mathrm{MH}$. Thermal and structural studies of poly (vinyl alcohol) and hydroxypropyl cellulose blends". Nature Science 2012; 4(1): 57-67.

https://doi.org/10.4236/ns.2012.41009

[31] Gallo JB, Agnelli, José AM. Aspectos do comportamento de polímeros em condições de incêndio. Polímeros 1998; 8(1): 23-38.

https://doi.org/10.1590/S0104-14281998000100005

[32] Banerjee SS, Bhowmick AK. An effective strategy to develop nanostructured morphology and enhanced physicomechanical properties of PP/EPDM thermoplastic elastomers, J Mater Sci 2016; 51: 6722-6734 https://doi.org/10.1007/s10853-016-9959-7

[33] Santos L. da S, Silva AH, Monteiro da FT da, Pacheco, E. B. A. V., Silva, A. L. N. da. Estudo do efeito da adição de PP reciclado nas propriedades mecânicas e de escoamento de misturas de PP/EPDM. Polímeros 2013; 23(3): 389-394. https://doi.org/10.4322/polimeros.2013.083

[34] Menard PK. Dynamic Mechanical Analysis: A Practical Introduction, CRC Press LLC: New York, 1999. https://doi.org/10.1201/9781420049183

Received on 24-01-2021

(c) 2021 Scagliusi et al.; Licensee Lifescience Global.

This is an open access article licensed under the terms of the Creative Commons Attribution Non-Commercial License (http://creativecommons.org/licenses/by-nc/3.0/) which permits unrestricted, non-commercial use, distribution and reproduction in any medium, provided the work is properly cited. 